\title{
perifèria
}

Número 20(2), diciembre 2015

revistes.uab.cat/periferia

\section{"Now, you are one of us" - participatory observation in the study of non-professional musical activities. A case study of Tuna Souselense.}

Rui Filipe Duarte Marques

Universidade de Aveiro - Departamento de Comunicação e Arte INET-md, Instituto de Etnomusicologia ${ }^{1}$

DOI: http://dx.doi.org/10.5565/rev/periferia.479

\begin{abstract}
This article takes as its starting point a case study of Tuna Souselense, a musical group founded in 1910, the year of the implantation of the Republic in Portugal. This study comprised two complementary perspectives: a diachronic view, based on archival research and a synchronic one, sustained in fieldwork. The project's implementation revealed a musical association in which predominates a family-type organization, scarcely opened to the action of external researchers. Furthermore, an inexistent split between musicians and audience marks the activity carried out by this group. Nevertheless, this separation is staged in public events. These features raised challenges that could only be overcome through participant observation as a conductor and an instrumentalist, which allowed me to establish dialogical interactions with musicians and other community's elements. How to study a musical field with such characteristics? How to understand the meanings attributed by these people to the act of making music together? What is its impact on the construction of individual and collective identities? These are the questions that guide my analysis.
\end{abstract}

Keywords: Tuna; local music; participatory observation; communities of practice; music and identity.

\section{Resumo}

Este artigo toma como ponto de partida um estudo de caso da Tuna Souselense, um grupo musical fundado em 1910, ano da implantação da República em Portugal. O estudo compreende duas perspetivas complementares: uma diacrónica, baseada

\footnotetext{
${ }^{1}$ Send mail to: Rui Filipe Duarte Marques rfdmarques@gmail.com
} 


\section{perifèria}

Número 20(2), diciembre 2015

\section{revistes.uab.cat/periferia}

em pesquisa arquivística, e outra sincrónica, sustentada em trabalho de campo. A implementação do projeto de investigação revelou uma associação musical na qual predomina uma organização do tipo familiar, pouco aberta à ação de investigadores externos. Além disso, a atividade deste grupo é marcada pela inexistência de uma separação clara entre músicos e audiência. Não obstante, essa separação é encenada em apresentações públicas. Estas especificidades constituíram desafios que apenas puderam ser superados através de observação participante como maestro e instrumentista, permitindo-me estabelecer interações dialógicas com os músicos do grupo e outros elementos da comunidade local. Como estudar um domínio musical com estas características? Como compreender os significados atribuídos por estas pessoas ao ato de fazer música em conjunto? Qual o seu impacto na construção de identidades individuais e colectivas? Estas são as questões que orientam a minha análise.

Palavras-chave: Tuna; práticas musicais locais; observação participante; comunidades de prática; música e identidade.

\section{Introduction}

This articlederives from an on-going research project within the framework of the Doctoral Program in Music, at the University of Aveiro, Portugal, under the scientific supervision of Maria do Rosário Pestana. My research consists on an ethnomusicological approach to a musical reality that, despite its cross spread to the whole Portuguese territory, its strong local presence and its ability to mobilize hundreds of non-professional musicians, has not been subject of study in Portugal: groups and musical associations named tuna.

This type of musical group, which differ from those described by Saus, Lagos and Gómez (Saus et al. 2003), has been documented in Portugal since the second half of the nineteenth century. Tunas are characterized by the flexibility of its instrumental constitution, the diversity of musical repertoires and the multiplicity of contexts in which they operate. For these reasons, the word tuna is used to refer to quite distinct musical groups. Within the scope of my research, this concept refers to a musical group wherein plucked string instruments like mandolin, mandola, mandocello, guitar and bass guitar are prevalent. However, the instrumental composition of tunas may also include bowed string instruments, wind instruments, percussion and even a voice section. 


\section{perifèria}

Número 20(2), diciembre 2015

revistes.uab.cat/periferia

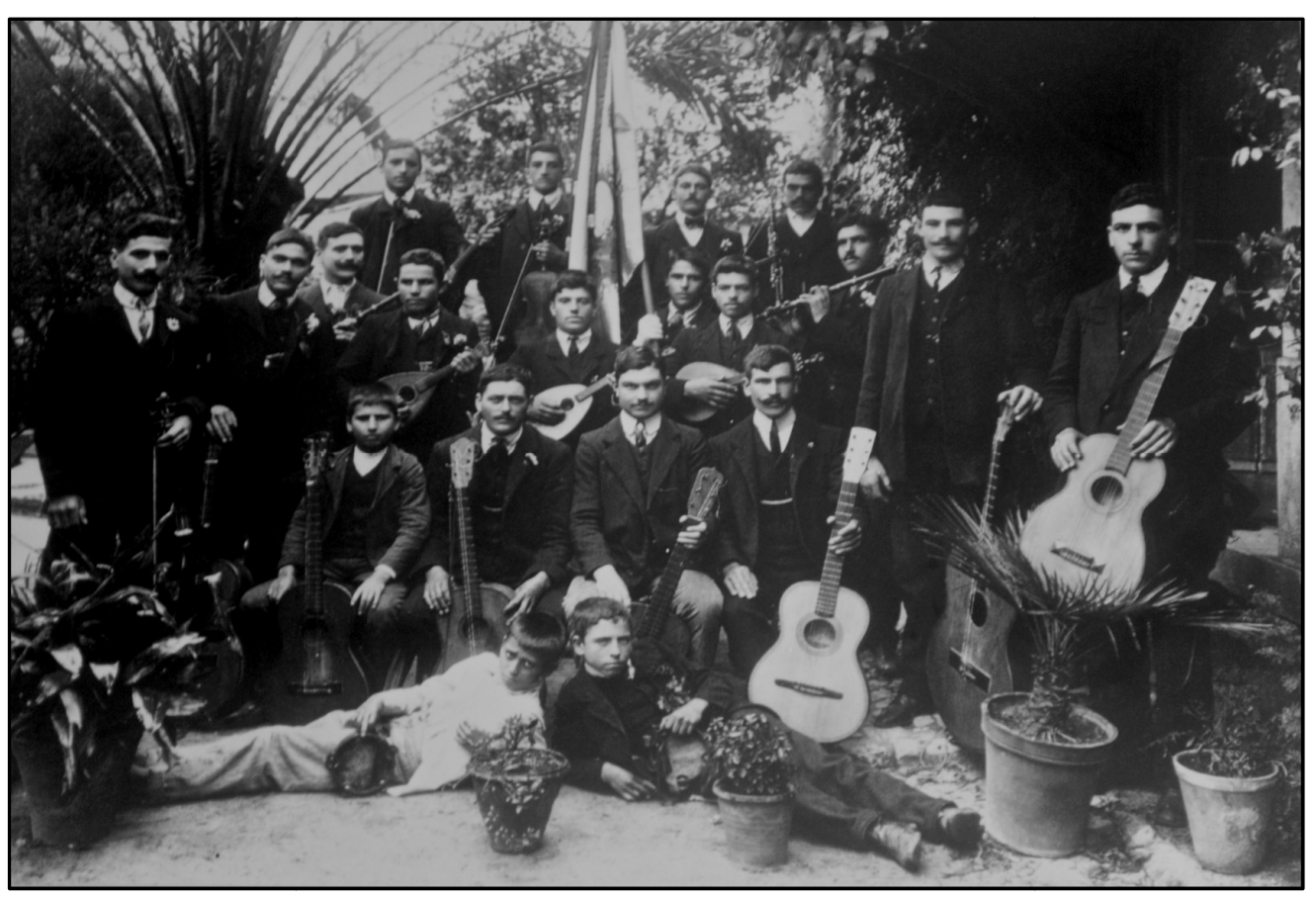

Picture 1: Tuna Souselense in 1910 (source: Tuna Souselense's archive)

This research takes as its starting point a case study of Tuna Souselense, founded in 1910 in Souselas, a village in the municipality of Coimbra, located in the centre of the country. According to the last Census, carried out in 2011, this village had a population of 3092 inhabitants. 


\section{perifèria}

Número 20(2), diciembre 2015

revistes.uab.cat/periferia
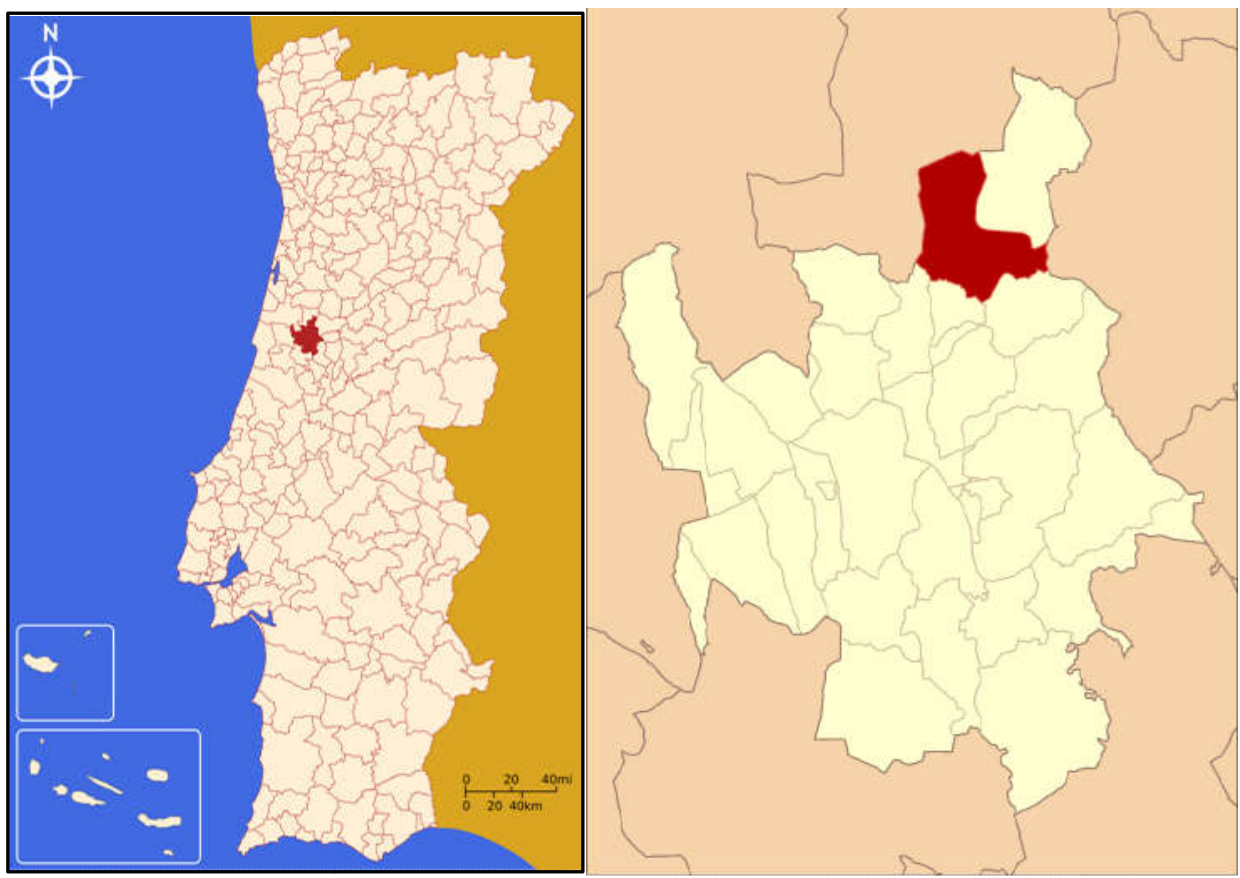

Pictures 2 and 3: Left and highlighted, Coimbra municipality. On the right side, Souselas location.

This paper focuses on the Tuna Souselense's activity at the present, and relies on fieldwork carried out between 2012 and 2014, comprising documentary research in regional periodicals, archives from several institutions and particular spoils, participant and non-participant observation and interviews with instrumentalists, singers and conductors of this musical group.

As I intend to reveal in this study, Tuna Souselense is an institution with a strong local establishment, in which prevails a family-type organisation, scarcely opened to the action of external researchers.Furthermore, an inexistent split between musicians and audience marks the activity carried out by this group. Nevertheless, this separation is staged in public events. These features raised challenges that could only be overcome through participant observation as an instrumentalist, which allowed me to establish dialogical interactions with musicians and other community's elements. This paper will discuss the advantages of this approach in the study of a musical field with such peculiarities.

Tuna Souselense - a brief (family) portrait of a local music practice 


\section{perifèria}

Número 20(2), diciembre 2015

\section{revistes.uab.cat/periferia}

Currently Tuna Souselense activity is mainly oriented to musical performance and an intensive pedagogical activity. Comprising about 20 instrumentalists and singers, this group includes people in different age groups and with heterogeneous social and cultural backgrounds, the majority of them developing professional activities outside the music realm. However, these people invest a significant amount of their free time in musical activities such as attending rehearsals and music classes in a weekly basis and taking part in concerts. Some of them are even involved in logistical and administrative tasks on behalf of the association. This striking commitment raises a question: what grounds the investment of nonprofessional musicians in performance practices undertaken within the context of locally organized musical associations?

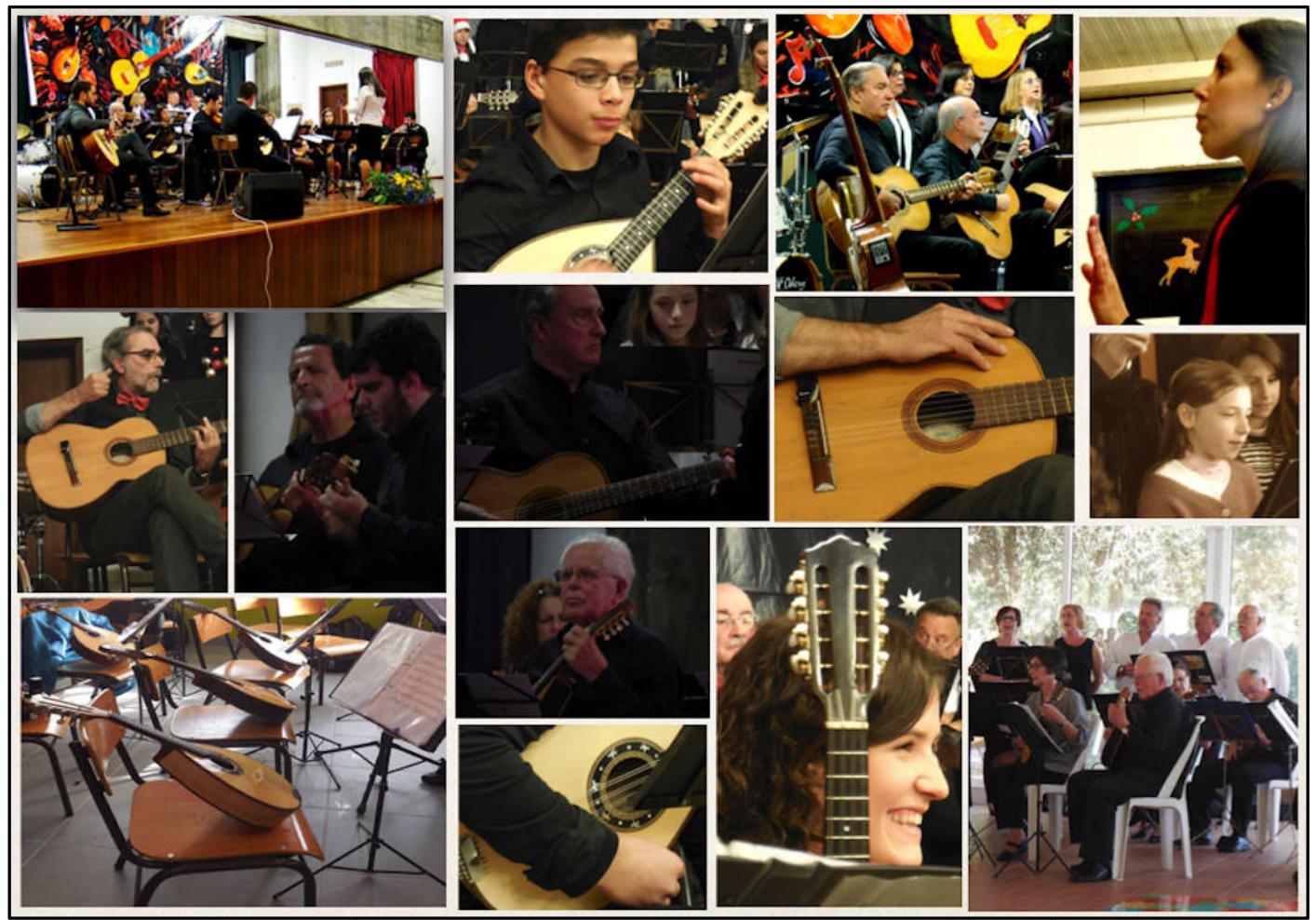

Picture 4: Some pictures taken in the course of fieldwork.

In this paper I refer to the concept of "local music" to describe those musical practices that require the direct participation of the inhabitants of a particular locality or geographical area. According to Ruth Finnegan, local music has the ability to involve its practitioners in the locality they live in, and is "a matter of 


\section{perifèria}

Número 20(2), diciembre 2015

revistes.uab.cat/periferia

active collective practice rather than just passive mass-controlled consumption or the solitary contemplation of musical works" (Finnegan 2007: 297).

What are the meanings attributed by these people to the act of making music together? What is the impact of music making on the construction of individual and collective identities? In an attempt to answer these questions, I turn to some testimonials gathered during the fieldwork, linking them with the concepts of "communities of practice" and "communities of musical practice" proposed by Etienne Wenger and Joan Russel, respectively.

\section{Theoretical framework}

Wenger's social theory of learning takes as it's starting point four premises: [1] the social nature of human being set up a central aspect of learning; [2] knowledge is rooted in a set of socially valued skills and actions; [3] knowledge's acquisition arises from an active participation in such actions and [4] the goal of any learning is to become able to interact with the world in a meaningful way (Wenger 1998: 4). The concept of "community of practice" plays a central role in Wenger's theoretical model, and stems from the interplay between four fundamental components: meaning, practice, community and identity. Joan Russel summarizes as follows the relationship between these concepts:

Meaning refers to our experience of life and the world, and practice refers to our shared historical and social resources. Community refers to the social configurations in which our enterprises are defined as worth pursuing, and our participation is recognizable as competence. Identity has to do with the ways in which learning creates personal histories for us in our communities. 'Practice'- characterized by mutual engagement, joint enterprise, and shared repertoire - is the source of coherence of community (Russell 2002: 3).

Wenger's notion of "community of practice" has been adapted to studies on music by Joan Russel, who proposed the concept of "communities of musical practice". This concept describes an organized group of individuals who found in musical performance a significant way of experiencing the world, sharing common historical 


\section{perifèria}

Número 20(2), diciembre 2015

revistes.uab.cat/periferia

and social resources in socially valued events in which their participation is recognized as a competence and through which their personal stories are inscribed in the community (Russel 2002: 2).

Based on the contributions of the abovementioned authors and based on the knowledge that results from fieldwork, I intend to discuss [1] how does the musical performance in the context of this tuna offers to its members a meaningful way of experiencing the world and [2] what is the impact of local music making on the construction of individual and collective identities.

\subsection{Eye to eye - musical performance as a way of experiencingthe world}

The dialogue established with Tuna Souselense's active elements allowed me to identify some reasons that lead these people to integrate this group. Besides its "love for music", the interviewees highlighted some extra-musical factors such as the familiar connections to other Tuna's elements or former elements, the sociability moments operated by music making and also emotional reasons, which are reflected in the establishment of affective bonds among elements of the group. All respondents identified the opportunity to participate actively in music making as their main motivation for belonging to Tuna. Regardless of the importance given to the act of singing or playing a musical instrument (actions recognized and valued as competences), the musician's discourse particularly stresses a valuation of the collective musical experience, as illustrated by the following passage:

I go [to the rehearsals] because I love music, and because I feel I'm making

progresses. At home, alone, I cannot stand to practice (interview to José Machado Lopes: 2014).

Moreover, the elements of this group express that, in this context, the "love for music" is connected to affective aspects. For these people, a rehearsal or a concert are not only musical events and opportunities for musical self-improvement, but also moments of meeting and socialising: 


\section{perifèria}

Número 20(2), diciembre 2015

revistes.uab.cat/periferia

[...] This is very much about human relationships, and of course here comes the conviviality, the pleasure of being with people. Well... I get an enormous pleasure in finding certain people, that little bit we're talking before or at the end of the rehearsal (interview to Carlos Cação: 2013).

This and other similar testimonies reveal the presence of several intentions converging to collective music making: the development of musical skills, the possibility of preparing, refining and publicly presenting a repertoire, the establishment and consolidation of interpersonal relationships and the possibility of intervening in the local community. This "way of experiencing the world", to quote Russel, is shortened by one interviewee musician:

Tuna is one of the moments when we may be eye to eye. Not only with those within, but also with those outside, through the concerts (interview to Carlos Cação: 2013).

\subsection{Now, I can rest peacefully - music making as a celebration of a collective identity}

Along the fieldwork I had the opportunity to note that the narratives of this institution emphasize the evocation of its emergence in 1910. Besides, most of Tuna Souselense's members refer to its musical involvement in a sense of continuity with the past:

My family has always been very... very integrated in Tuna. And it means something for us. [...] My grandfather played there... and his brother... and the other one... at least three of them. And currently me and my cousin. [...] It's a motivation; I mean... it drives us! This turns out to connect us more (interview to Carlos Cação: 2013).

Furthermore, the collective recognition of the people responsible for the group's emergence is evident. Connection to these people is reflected in several gathered testimonies, as well in consecration rituals of Tuna's founders, who are honoured in 


\section{perifèria}

Número 20(2), diciembre 2015

revistes.uab.cat/periferia

public events or through the permanent exhibition of his photographs and their musical instruments in institution's prominent places. In my opinion, the constant references to Tuna Souselense's advent and on the role of prominent members in its early years contribute to build and consecrate a collective identity. This valuation of the "origin" seems to legitimate the role of the group in the present. Moreover, the desire of continuing a "bloodline" of people connected to this tuna is a stimulus to participation in this institution's life.

The sharing of a common historical and social context is also oriented to the future. One of the musicians, who collaborate with this group for about 20 years, highlights the fact that his father was one of the Tuna's founders, in 1910. When I asked him about what had been the most significant moment over the course of his permanence in the group he said, visibly moved:

Has been recently. Now, I can rest peacefully. I've already seen my grandson

playing by my side (interview to Armando Cação: 2013).

\section{Take this mandolin and play with us - participatory observation as a turning point}

As I intended to demonstrate in the previous section, Tuna Souselense's action is shaped by a predominantly family-type organization. This circumstance pervades the boundaries of this group's performance space. Indeed, musician's families interact in Tuna's activity, not only as a substantial part of its audience, but also actively participating in the organization of public events held in Souselas. In this way, music making manage to build a network of personal relationships surrounding this musical group, and this produces a significant impact, given the relatively small dimension of the locality.

The first fieldwork stage comprised gathering historical records (music scores, correspondence, photos, etc.) and non-participatory observation, carried out in rehearsals and concerts. Regarding to the document gathering, the "family aura" surrounding Tuna made it difficult to access to most of the documents, seen as personal and intimate. When I began to attend rehearsals, I found that my 


\section{perifèria}

Número 20(2), diciembre 2015

revistes.uab.cat/periferia

presence there, as a passive and outsider spectator, was breaking its fluidity. Attending to concerts, I realized that despite of an almost inexistent split between musicians and audience, this separation was staged in public events.

The beginning of participatory observation provided a turning point in the research, allowing me to overcome some difficulties. By the end of 2013 I started to attend rehearsals and concerts as a mandolin player, leaving behind the outsider condition. About 6 months later one of the older musicians told me: "Now, you are one of us". I was witnessing a remarkable shift in the relationship to these musicians. From then on, I was allowed to access to documents held by musicians and their families, went to interview people in their home environment and started to be invited to participate in convivial moments. The abovementioned shift allowed me to observe not only the content (the performed music), but also the context or, in the words of Marcia Herndon, the "occasion":

The occasion may be regarded as an encapsulated expression of the shared cognitive forms and values of a society, which includes not only the music itself, but also the totality of associated behaviour and underlying concepts (Herndon 1971: 340 quoted in Béhague 1984: 5).

Participatory observation as an instrumentalist enabled me, as Jeff Titon states, to ground fieldwork in a "musical being-in-the-world", valuing "music as the basis for knowing people making music" (Titon 2008: 38). This way, musicians felt themselves comfortable sharing their views on the music they play and on the meanings of this practice in their own live.

\section{Final comments}

Wenger's conceptualization of "communities of practice" proved to be helpful in the study of this particular music domain.However, in the Tuna Souselense's particular case, the relationships that emerge from the musical practice intersect with familiarconnections, which contribute to the complexity of the sociability's web generated within this musical group. 


\section{perifèria}

Número 20(2), diciembre 2015

revistes.uab.cat/periferia

Research revealed that Tuna Souselense has the capacity to bring together individuals who found in musical performance a significant way of experiencing the world, sharing common narratives in socially valued events such as rehearsals and concerts, which configures "occasions" to the inscription of their personal stories in the place they live in. Future approaches should contribute to the understanding of the multiple roles taken over by the conductor in nonprofessional musical contexts, the musicians' relation to musical repertoire, as well as the impact of musical practices of this group in the building of social networks at the local level.

This paper is also a testimony of my own fieldwork experience and is meant to discuss the rewards of participatory observation. Quoting Titon again, fieldwork is about "establishing a sound and hopeful relationship before getting down to purpose" (Titon 2008: 38) or, for short, "You have to know how to visit" (idem).

\section{Bibliography}

Béhague, Gérard(1984). Performance Practice - Ethnomusicological Perspectives. Westport and London: Greenwood Press.

Finnegan, Ruth (2007) [1989]. The Hidden Musicians - Music-Making in an English Town. Middletown: Wesleyan University Press.

Instituto Nacional de Estatística(2011). "Censos 2011" inhttp://www.censos.ine.pt [accessed 18/06/2015].

Russel, Joan(2002). "Sites of learning: communities of musical practice in the Fiji Islands. Focus Areas Report". Bergen: ISME.

Saus, Antonio, Lagos, José and Gómez, Emigdio (2003). Cancionero de estudiantes de la Tuna - el cantar estudiantil, de la edad media al siglo XX. Salamanca: Ediciones Universidad de Salamanca.

Titon, Jeff (2008). "Knowing Fieldwork" in Shadows in the Field - New Perspectives for Fieldwork in Ethnomusicology, edited by Barz, Gregory e Cooley, Timothy, 2541. New York: Oxford University Press. 


\section{perifèria}

Número 20(2), diciembre 2015

revistes.uab.cat/periferia

Wenger, Etienne (1998). Communities of Practice - Learning, Meaning and Identity. New York: Cambridge University Press.

DOI: http://dx.doi.org/10.1017/CBO9780511803932

\section{Quoted interviews}

Agante Ferreira (Fornos, November 2013)

Armando Cação (Souselas, December 2013)

Carlos Cação (Souselas, December 2013)

José Machado Lopes (Pampilhosa, February 2014) 